\title{
"Ageism" in Brazil" What is it? Who does it? What to do with it?
}

\begin{abstract}
Ana Maria Goldani**
The main goal of this article is to call attention to ageism and age as a part of the Brazilian system of prejudice and discrimination. Although ageism and age discrimination are often used interchangeably, ageism refers essentially to the system of attitudes so often attributed by individuals and society to others by age, while age discrimination describes a situation in which age is the deciding factor. An example of age discrimination is when an employer decides to recruit, to promote, to retrain or to retire/dismiss an employee based only upon age. While noticing someone's age is not inherently offensive, acting on age-based stereotypes clearly is a prejudice against the individual that often goes unchallenged by mainstream society. This article relies on empirical findings and the cumulative knowledge on discrimination of the elderly, and discusses theoretical positions that link age discrimination with ageism. We argue that ageism and the practice of age discrimination in Brazil should be viewed as part of the multiple forms of discrimination experienced by individuals. A central assumption guiding this paper is that the way we frame ageism and intergenerational relations has a significant effect on both perceived age discrimination and support for age-based social programs and it will be illustrated for the Brazilian case.
\end{abstract}

Keywords: Ageism. Policy. Inequality. Demographic changes.

\section{Introduction}

Our everyday social judgments are frequently age-based, even if we consciously deny them (MACNICOL, 2006). The stereotypical and often negative bias describing age groups, in particular older adults, is called "ageism". "Ageism, as any kind of discrimination, can essentially be thought of applying assumed age-based group characteristics to an individual, regardless of individual characteristics" (MACNICOL, 2006, p. 6). Ageist beliefs and attitudes may not, in and of themselves, be harmful. However, age discrimination occurs if these beliefs and attitudes legitimate "the use of chronological age to mark out classes of people who are systematically denied resources and opportunities that others enjoy, and suffer the consequences of such denigration, ranging from wellmeaning patronage to unambiguous vilification" (BYTHEWAY, 1995, p.14). Ageism is considered the ultimate prejudice, the last discrimination, the cruelest rejection and the third great "ism" after racism and sexism

\footnotetext{
* This article is an extended and somewhat different version of "Desafios do 'Preconceito Etário' no Brasil”, published on Educação e Sociedade, 111, vol. 31-abr-jun-2010. Revista de Ciência da Educacão. Cedes/Unicamp.

${ }^{* *}$ Associate Research Professor, Department of Sociology and Office of Population Research, Princeton University.

1 The term ageism was coined in 1968 by Robert N. Butler, MD, a pioneer in geriatric medicine. He was among the first to identify and describe the phenomenon of age prejudice, initially defining it as "a systematic stereotyping of and discrimination against people because they are old".
} 
(PALMORE, 2004, p. 1). Ageism like racism depends on stereotyping. The destructive impact of ageism occurs in three main areas: social prejudice, discrimination in the workplace and bias in the healthcare system (BUTLER, 1980).

Brazil, like most modern societies is highly age-stratified and age-conscious and displays complex shifting attitudes towards its older citizens. However, awareness and assessment of the negative impact of age discrimination are scarce. Social prejudice is the most studied area, followed by age bias in the health care system and discrimination by age in the working place. Health professionals, gerontologists and social psychologists have authored most of the studies, focusing on the negative perception and discrimination of elderly people (among others COUTO, et al., 2009; CACHIONI; AGUILAR, 2009; SOUZA, 2003; SIMSON; NERI; CACHIONI, 2003; NERI, 2003, 2005; DEBERT, 1999; FREITAS et al., 2002; VELOZ et. al., 1999). The idea that age is the potential basis of division and conflict between generations and as such represents a threat to intergenerational solidarity, is an issue that is being addressed in Brazil (BARROS; CARVALHO, 2003; TURRA; QUEIROZ, 2009; GOLDANI, 2005; NERI, 2003).

Our initial argument is that age discrimination and stereotypes are social problems which society must confront and defeat through awareness, education and policy intervention in order to seek universal equality. Efforts in this direction are recent and come from industrialized societies where age discrimination is a highly topical issue against a background of concerns about shortening working lives and ageing populations in the future. For the first time, age discrimination has been made unlawful by the European Union and, as a result, there are now laws in every Member State making such discrimination unlawful (SARGEANT, 2008; AGE CONCERN ENGLAND, 2008).2

We argue that age discrimination and the ageism debate in Brazil should be understood through the approach of multiple discriminations. This requires that we consider the perspective of intersectionality, which encompasses the idea that people can simultaneously experience oppression and privilege based on certain individual characteristics and depending on the context of the situation. In some cases, grounds such as sex, race, age or disability, to name just a few, may intersect and together produce unique effects, creating what Towsend calls "discreet and insular minorities" who are socially handicapped because of these characteristics. At other times, any one of these characteristics may intersect with other characteristics such as social assistance, family status and economic, social and class status to create unique experiences for individuals. Even when combined with other grounds such as social assistance and family status, the extent of discrimination may not be revealed by a traditional, non-intersectional approach (TOWSEND-BELL, 2009).

Therefore this article aims to convey three ideas. First, ageism in Brazil is mainly associated with old age individuals and can be understood under different perspectives. In the fields of health and gerontology the emphasis is on the prejudices perceived through age stereotypes and the social position of elderly people. From the perspective of ageist policies, the evaluation of the elderly is positive and they are considered privileged and even responsible for the financial difficulties of the social security system. Second, ageism in Brazil should be addressed in the context of multiple discriminations. Although discussions of economic and social inequalities often address the role of discrimination, discrimination is generally

\footnotetext{
2 Equality Bill 2009, which aims to consolidate and (to some extent) modernize and clarify existing discrimination legislation across all protected grounds, has generated much debate. For example, some religious leaders in England are opposed to the act that it, like existing legislation, restricts the freedom to discriminate on grounds of sexual orientation as a result of the discriminator's religious beliefs (FLASH REPORT, 2009).
} 
restricted to race, gender and class. Age is not considered another "ism". Third, age discrimination should be a matter of intervention and even new legislation. Facing the traditional tension between scholarship and activism, we conclude with recommendations to identify and address age discrimination and ageism in the context of current anti-discriminatory Brazilian policies.

\section{How widespread is discrimination in Brazil}

Despite Constitutional guarantees, discrimination is part of the everyday life of Brazilians in various settings and at different levels (e.g. government and private labor markets). Many government regulations in public employment prevent discrimination by age and sex. The federal law establishes that $10 \%$ of government jobs go to individuals with special needs. ${ }^{3}$ However, social programs and policies established with a particular age group in mind can inadvertently discriminate against persons in other age groups. Thus, Brazilian social policies that target the elderly, children, youth and women in reproductive ages may be viewed as discriminatory. In the private sector, constitutional rights are not enough to avoid discrimination.

In a nationally representative survey in 2008 at least 10 percent of Brazilians answered that they felt discriminated or mistreated due to their physical appearance or the way they talked in places like governmental institutions, in social gatherings or in public spaces and especially when looking for a job (LAPOP SURVEY, 2008). It is important to note that not only Brazilians are victims of discrimination. Compared to Colombia and Mexico, discrimination reported by individuals when searching for a job varies from $10 \%$ in Brazil and $11 \%$ in Colombia to $18 \%$ in Mexico. From the same source we also found that $7 \%$ of Brazilians have been a victim of police mistreatment at least once in the past twelve months and younger urban males are the most frequent victims of police action (LAPOP, 2008). Controlling for individual characteristics, Brazil ranks among the six highest countries regarding police mistreatment along with El Salvador (8.2\%), Argentina, (7.7\%), Bolivia (7.5\%), Colombia (6.9\%) and Peru (6.6\%). The analysis of socio demographic variables show that gender, age and size of city of residence are closely related to police abuse in the twenty Latin American countries (CRUZ, 2009).

We know very little about discrimination by age in the labor market but some findings indicate its presence even among an already discriminated group, such as disabled workers. For example, a cross-sectional study on permanently disabled workers in Belo Horizonte, which evaluated factors associated with their chances of readmission into the labor market, found that the most decisive factors for their readmission were age, presence of repetitive strain injury (RSI), and educational level. The most favorable segment was for those with RSI, under 40 years of age and with average schooling (75.6\%). Results showed that young male workers with high educational levels were the ones with the best chances of rejoining the market (90.9\%). A controversial issue related to workers' acceptance and program results is that the worker had to display a particular age and educational profile. Workers with $\mathrm{RSI}$ had this profile, but once accepted they were the ones with the greatest difficulty in rejoining the work force. In addition, additional discrimination against female workers was observed, despite their similar characteristics to those of males (SAMPAIO et al., 1999).

\section{Which people would Brazilians not like to have as neighbors?}

The World Values Survey in 2006 showed that almost $5 \%$ of Brazilians said they wouldn't like to have an elderly person as a neighbor in 2006. The good news is that among the 16 groups of people asked

3 We thank the anonymous reviewer for this clarification. 
as potential neighbors, the elderly were the least rejected. Drug addicts, "minor troublemakers", heavy drinkers, former prisoners and prostitutes were the least desirable neighbors, in that order (Figure 1). Respondents were allowed to mention multiple groups, and among the responses, only $1.3 \%$ of all answers were against the presence of an elderly as a neighbor. The least desirable group of people to have as a neighbor were drug addicts (20\%), followed by minor-aged troublemakers and heavy drinkers, each with about 15 percent of rejection. Another group of undesirable neighbors were prostitutes and former prisoners with about 10 percent of rejections each, followed by homosexuals with 6 percent, people with AIDS, mental health problems and favelados (shantytown residents) at 4 percent each; representing less than $2 \%$ of rejection were immigrant workers, foreigners, unmarried couples, persons of different religions, non-white people and the elderly (Figure 1).

\section{Is there medical ageism in Brazil?}

Gerontological literature on ageism has long criticized the not-so-subtle ways in which the last stage of life is diminished (WILLIAM, 2004; BERNARD et. al., 2003). Doctors dismiss seniors' aches and pains as an inevitable part of aging rather than probing deeper, as they would for younger patients, and then many older people as well as their caregivers seem to internalize the message and fail to seek a second opinion or one from a geriatrician. This would respond to an assumption that everyone over 60 has the same health needs and it is called medical ageism (GERENCHER, 2003). Evidence of medical ageism in Brazil comes from AIDS statistics in the 2008 report on the global AIDS epidemic, which shows that the number of HIV positive Brazilian women aged 50-59 doubled between 2000 and 2007. Among those aged 60-69 the number grew by 88 percent and those over 70 years had an increase of 190 percent.

FIGURE 1

Percentage of respondents who mentioned the following groups as people they would not like to have as neighbors $(n=1,485)$

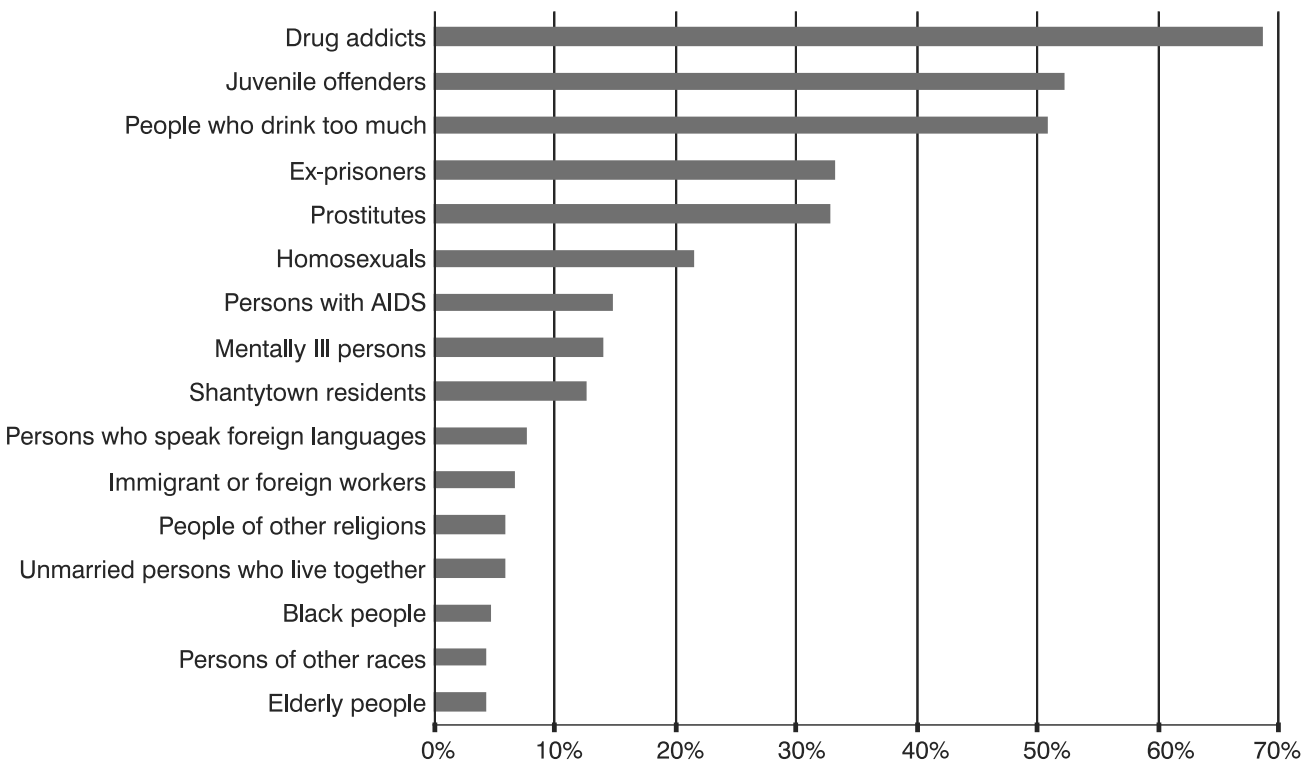

Source: World Values Survey, Brazil 2006.

Note: Respondents were allowed to mention multiple groups. 
Although less pronounced, there was a trend of increasing numbers among males as well (VALENTE, 2008).

The sharp increase in AIDS among older women in Brazil and some other countries in Latin America ${ }^{4}$ generated a debate on the potential causes and are illustrative of ageism. An important group of causes has to do with the vulnerability of older women for no longer being in reproductive ages. Since there is no risk of pregnancy, there is less concern over using condoms, and at the same time after menopause women are more vulnerable because vaginal tissues are more fragile. Also, in a gendered context, women's negotiation with partners to use condoms seems to be more common in unstable unions. Therefore, even in a time of a spreading use of Viagra, the assumptions seem to be that older people are not sexually active and that their sexuality somehow disappears at a certain age. A concrete side effect of this ageist approach is a late diagnosis of AIDS among the elderly. Even when they develop AIDS symptoms, the problem remains hidden under other pathologies that are common in the process. Finally, in terms of sexuality among older people, researchers often overlook the risk of sexually transmitted diseases spreading among the elderly (see various expert opinions in VALENTE, 2008).

\section{A profile of discrimination of the elderly in Brazil?}

(...) old Brazilians do not exist. There are several old age scenarios referenced to different individual and social quality of life status. (NERI, 1993, p.39, our translation)

There is no single aging model in Brazil and several studies describe the complexity of drawing a profile of negative or positive perceptions and attitudes without considering the context of individuals' family, professional and personal lives (CACHIONI; AGUILAR, 2008; NERI, 2003; NERI; JORGE,
2006). Changes in the notions and values associated with the aging process were documented in urban Brazil through printed media articles during 1967-2002. Historical changes include a transition of aging from a "divine to more worldly concern"; from a "male to predominantly female concern"; from "old age' to 'third age".' These transitions are intertwined with new moral hierarchies, and are linked to the medicalization of old age in the late twentieth century (LEIBING, 2004).

Other studies suggest that there is an overall improvement in intergenerational understanding, health status of the elderly and young people's attitude toward old age. Through often enjoyable interactions, young and elderly people have improved their understanding and view of each other. An example is the perceptions of some groups of students revealing how much they feel free to talk to elders and how their contact with elders made them more peaceful (SOUZA, 2003). The quality of the relationship between grandparents and their grandchildren is also explored through the exchange of experiences in the process of generational identity. Some findings reveal the importance of the greater diversity of the family environment in mediating the relationship between youth (ages 1-18) and the elderly (ages 62-78) and concluded that there is an effective exchange of knowledge, values and care activities between these two groups (SCHMIDT, 2007).

The only Brazilian study comparable to international surveys on ageism that I found was done in the South of Brazil (COUTO et al., 2009). It sought to identify the predominant types of discrimination against the old and to measure their relationships with levels of stress. Based on similar questionnaires, findings were compared to Portugal and the United States. Despite some problems of comparison (no national sample for Brazil and sample selectivity of those with better health and those attending

\footnotetext{
4 In Chile 10 percent of HIV positive individuals are older adults and figures are increasing according to Juan Molina (quoted on alente 2008). In Mexico, where the AIDS prevalence is lower than in other Latin American countries, $11.7 \%$ of HIV positives are over 45 years old according to the National Centre for the Prevention and Control of HIV/AIDS (CENSIDA) (VALENTE, 2008)
} 
organized senior organizations), the authors concluded that the most common types of discrimination were related to the social context and health of individuals. Based on a summary indicator of ageism using the frequency and type of discrimination and its associated level of stress, the findings show that ageism was not differentiated by sex, age, years of schooling and self-reported health. However, the level of ageism was greater in those cases in which the elderly were less satisfied with their socioeconomic status.

Contrary to their expectations that levels of stress for the majority of the discriminatory aspects were, on average, very low, the authors concluded that the experience of discrimination is not necessarily explicitly associated with stress. The authors also suggest that the elderly could be using different strategies to cope with negative discrimination. At the same time they noticed the nature of the sample, in which the elderly were members of the so called Groups of the Third Age (Grupos da Terceira ldade), in which members are stimulated by activities and conferences to think positively about their age, which potentially helps to increase their self-esteem and more easily deal with prejudices (COUTO et al., 2009).

Regarding national comparisons on ageism among the elderly, they found both differences and similarities with Portugal and the United States. As expected, the experiences of age discrimination for elderly Brazilians and Portuguese tended to be more similar than between Brazilians and Americans. The highest levels of violence were suffered by the Brazilian elderly, which is compatible with the general levels of violence in that country. In conclusion, this study suggests that the Brazilian findings endorse the idea that ageism is a generalized and transcultural phenomena.

TABLE 1

Social inequality indicators

Brazil - 2007

1. Number of families comprised of couples with children and with a woman head of household (million) 3.1

2. Mean schooling of employed population (16+)

White men

Black men

Black women

3. Proportion of women $25+$ who have had breast examination according to place of residence Urban

Rural

4. Distribution of households with Bolsa Família

With white household head

With black household head

5. Unemployment rate of population age $16+$

White men

Black men

Black women

6. Proportion of domestic servants with social security (registered employment card)

White women

7. Proportion of urban household heads living in favelas

White men

Black men

8. Income ratio by sex

White females/white males $\quad 62.3$

Black females/black males $\quad 67.0$

Black females/white males $\quad 34.0$

9. Mean hours in domestics tasks per week (16+)

Men

Women

Source: Pinheiro, L. et al. (2008). 
Finally, the limitations of historical evidence about everyday life and social attitudes in Brazil mean that it is at least as hard to generalize about past ageism as it is about its contemporary character. However, the above findings are clear indications of its presence and the nature of current ageism. We can better understand it in the context of economic and social inequalities, as illustrated in Table 1. Therefore, as suggested earlier, to better understand and discuss policies to combat ageism and age discrimination in Brazil we should consider the context of multiple discriminations and their intersectionality.

\section{Ways to Understand Age Discrimination and Ageism}

The origins of ageism are discussed using different perspectives. At one end, there are psychological explanations suggesting that ageism has deep roots that are irrational and associated with our fears of death, our own ageing and physical and mental decay (BUTLER, 1980). At the other end of the spectrum, the economic explanations suggest that modern capitalist economies marginalize older people by enforcing retirement and idleness, involving a lowering of economic and social status. From this latter perspective, comes the assumption that the average male worker becomes unproductive at age 65, even though this age and older includes individuals with a wide range of abilities (MACNICOL, 2006, p. 11).

A common approach in ageism is that globalization and modernization should be blamed for an apparent shift in attitudes toward older people. The idea is that many non-Western cultures exposed to a global economic model have recently undergone social and economic structural changes that decrease both the status and the competitiveness of older people (LOGUE, 1990; CUDDY et al. 2005). Industrial societies lower the status of older people, through four mechanisms. First, medical progress increases the size of the elderly population, which institutionalizes retirement and removes older people from prestigious positions. Second, technological skill eclipses experience as technological advances create new jobs, which also puts older people out of work. Third, young people become more transient, losing ties with older relatives. Fourth, increasing literacy renders oral traditions obsolete, eliminating the position of seniors as sage. These changes in status are linked to the elimination of older people from competitive social roles. In brief, social changes decrease the status and competitiveness of older people, thus creating the warm but incompetent elderly stereotype (CUDDY et al., 2005).

Another largely-used approach is the "just allocation of resources" between generations and age groups which has been recovered in the past twenty years, particularly in the United States and Britain. This perspective, also known as the 'generational equity debate', can be traced back to tribal societies in which anthropological literature documents intergenerational tensions. It can also be traced to Thomas Hobbes and other 'social contract' theorists, and developed by several social theorists, including Karl Manheim (1957) in his classical work "The Problem of Generations", and in the work of moral philosophers like John Rawls and Bruce Ackerman (MACNICOL, 2006). In fact, there are different perspectives on intergenerational relations in public discourse and policy decisions (WILLIAMSON; WATTSROY; KINGSON, 1999). Political groups frame the debate on age-based "entitlements" in ways that are either favorable or unfavorable to social spending initiatives (QUADAGNO, 1996). Recent studies have investigated the prospects for increasing the average retirement age and consider the challenge of ensuring a secure retirement for low-wage workers and those unable to continue to work (MUNNEL; SAAS, 2008). At the heart of this debate is whether funding for social programs that benefit particular age groups should be eliminated. Calls for "generational equity," for example, may be seen as political strategies to legitimize reductions in government spending.

The "political economy of aging" arose in part as a critique of the analytical limitations of the theory of age stratification, conventionally used to explain the relationship between 
intergenerational relations and welfare. A basic criticism refers to the excessively narrow concentration on chronological age and birth year, which diverts attention away from individual responses to the aging process and from differences within age-cohorts deriving from macro-structural factors such as class, gender and race. In other words, the many experiences affecting older people are "a product of a particular division of labor and structure of inequality rather than a natural concomitant of the aging process" (WALKER, 1993, p. 143). Aging and social inequality in the perspective of political economy theorists have located social structure at the heart of their analyses. They have explained the relative situation of older individuals by focusing on the interrelationship between the economy, the policies, and the ideological structures that these systems of domination construct and reconstruct. In this approach, age discrimination (behavior) is not viewed as a simple consequence of an ageist ideology (attitudes based on negative stereotypes). Nor are ageist attitudes or age discriminatory policies seen as direct results of an inability of the individual to adjust to aging, naturally diminishing physical or mental capacities. Current arguments are that globalization brings forth a new set of actors and institutions influencing the social construction of public policy for old age. Thus, ageism may be a consequence of, or provide a legitimating ideological foundation for, discriminatory age patterns.

The social construction of age as an organizing feature of social life is recognized in the political economy approach, and structural factors that limit the opportunities of older adults are at the core of these analyses. Missing in most political economy accounts is an analysis of the relationship between age relations and class relations as they structure social inequality at various life course stages. Also, structured social relations are based on the varied rights and privileges that define social relationships (WRIGHT, 2000). Hence, a relational understanding of age requires an emphasis on "structured forms of power, organization, direction, and regulation that exist in modern societies and through which ruling groups maintain and reproduce their dominant positions" (LAYDER, 1994, p. 159).

A gender approach in discussing ageism and age discrimination points to the labor market, where employment follows the more valued male-based chronology of career development and continuous employment. Career discontinuities arising from family and domestic responsibilities impact disproportionately on women, and may become particularly apparent after the age of forty. Moreover, because working women often stay longer in the labor force than men, there is a tendency to believe that they do not suffer from age discrimination. However, uneven patterns of pension fund contributions rule out "early exit" for most women. The growing participation rate for older women in the labor force does not mean that older women suffer fewer agerelated disadvantages than men. Findings for the U.K. indicate that across age groups, women provide many examples of negative ageist attitudes associated with appearance. And even young women, those in their 30's, reported that they had been considered "too old" for promotion. In fact, there was evidence that for promotion, women were considered "older" at an earlier age than male colleagues. Thus, ageist experiences were associated with much earlier earning peaks for women than for men and the authors concluded that "being female tended to intensify age prejudice and 'double jeopardy' was reinforcing rather than simply additive" (LORETTO et al., 2002).

In the United States studies note that the ignorance of old men's masculinities is rooted in practices of ageism (Berger, 1996). Unlike discussions of masculinity and class, ethnicity, sexuality, or religious background, rarely has aging been contemplated when masculinities are discussed. In most discourses one can be masculine and one can be old, but not both. As much as femininity has been a boundarydefining yardstick for what masculinity is not, for the past two centuries "old" has also been incorporated as a cultural gauge for what masculinity is not (KIMMEL, 1997; THOMPSON, 2004; DAVIDSON, 2004). Normative masculinity became and 
remains embodied by middle-aged and younger men, both in mass culture and in men's studies. However, if straight seniors must struggle against becoming invisible as they age, gay elders have been almost non-existent in society's mirror. There are many damaging myths about the loneliness and unhappiness of older gay men and lesbians. But research into the experience of aging in GLBTQ communities suggests that homosexuals adjust to aging as well as heterosexuals (WOOLF, 1998).

Finally, there is the previously mentioned intersectionality approach that first and foremost reflects the reality of lives and which we suggest is the most appropriate way to understand ageism and age discrimination in Brazil. One central idea of this perspective is that there is no single identity category that satisfactorily describes how we respond to our social environment or how it is responded to by others (TOUWSEND, 2009). From this point of view, intersectionality is more than interlinking identities resulting from social stratification. It argues for the consideration of individual experience, and as such intersectionality would be defined as crossing disciplinary boundaries. It is "the recognition that structures/systems - and the categories of difference that result from them - overlap in inextricable ways in the lived experience of social groups and individuals, and that these are mutually reinforcing and inseparable from one another, even where they do not appear to operate in such a fashion" (TOWSEND-BELL, 2009). The intersectional discrimination approach can be linked to a sociological tradition of studies on race, gender and class which gained relevance among American Black feminists in the 1980s, who improved and spread that discussion (COLLINS, 2000; CRENSHAW, 1995).

The failure to capture the structural and dynamic consequences of the interaction between two or more forms of discrimination has only recently been recognized in international forums, as a serious obstacle to the achievement of equality for many marginalized individuals. This notion has been acknowledged by a series of UN conferences on women and a more recent extension of this approach is the European Union's proposal to broaden the principle of equal treatment among individuals (THOWSEND-BELL, 2009). Acknowledging intersectionality among the various forms of discrimination, a new EU directive sets out a framework for the prohibition of discrimination on the grounds of sex, racial or ethnic origin, age, disability, sexual orientation, religion or belief and establishes a uniform minimum level of protection for people who have suffered such discrimination. The anti-ageism movement uses a social justice perspective that holds as ideal, the possibility of an 'age-neutral' or 'age irrelevant' society. This is much like a "gender blind' or 'race blind' concept of society in which individuals would be judged by their character rather than by their chronological age (MACNICOL, 2006, p. 17).

The intersectionality approach also gains greater visibility in the area of human rights and it has proved to be instrumental for discussing complaints in international forums. Several cases can exemplify the risks of not using an intersectional approach in many sexual discrimination and harassment cases. For example, sexual harassment cases tend to proceed on the basis that the race, ethnic origin, or ancestry of the alleged harasser and the complainant are not relevant. However, there may be stereotypes on the sexuality of women based on their race, ethnic origin, ancestry or place of origins. Factors such as age, marital status, and sexual orientation can also be relevant.

In conclusion, the different theories mentioned above are part of a wide range of perspectives that shape the debate about the extent and nature of an aging society. Most of these theories are primarily macrooriented, thus neglecting the diversity of cultural meanings among older people and the voices of older people (GILLEARD; HIGGS, 2000). For example, the political economy approach overemphasizes structural disadvantage or structured dependency at the expense of attention to older people's agency in resisting poverty. A criticism of gerontologists is that such sociological theories that focus upon the 
social problems of older people may support the ageism of which many argue against. An argument is that there is an increasing diversity of experiences of aging and the pace of cohort differentiation is speeding up. These trends reflect cohort differences in terms of life chances that are created by period specific conditions, policies and economic transformations.

Thus, some gerontologists affirm diverse subjective experiences of aging in the lifestyles of older people. With this assumption gerontologists have developed some postmodern theories of aging identity and they also have been criticized, especially for their failure to consider more broad-based social and life course approaches (POWELL, 2001). Powell proposes to look at Foucault's work, mostly because his analyses of power are relevant to older people's experiences. This includes Foucault's description of how the patient, the madman, and the criminal are constructed through disciplinary techniques, as in his work on the "medical gaze" (1973, p. 29). Older people's relationships with professional social workers could be similarly constructed. Second, Foucault (1977) offers a methodology that examines both the official discourses on social policy and the social workers and older people operating within these discourses. The understanding of institutionalized practices in old age allows activists to broaden their scope for political action (POWELL, 2001).

\section{The brazilian experience from different perspectives}

The generational equity debate in Brazil gained momentum under the international and national debates over social security reforms and the increase in social spending in the 1990s. A central premise of the often-discussed "intergenerational equity debate" is that divergence among specific age segments of the population are well marked and that younger, middle and older generations are in competition with each other for scarce resources. In discussing the intergenerational allocation of resources, some Brazilian economists assume that children and youth are a greater investment than the elderly, based on costs to public finances and social spending (BARROS; CARVALHO, 2003). Participating in this debate, we stressed the need for policies to consider how norms of obligation, reciprocity and expectations between generations are negotiated at both the micro-social level of the family and the macro-level of society (GOLDANI, 2005).

The "clash of generations" in Brazil, whether actual or perceived, real or invented, has come to the center of policy discussions about the elderly population as well as into popular awareness through mass media (GOLDANI, 2005; NERI, 2003). Recent work concerned with the financial health of the social security system against a background of demographic changes are acknowledging both a "conflict" of interest among age groups and a "demographic imperative" linked to social policy (TURRA; QUEIROZ, 2009; GIAMBIAGI, 2010). The continued debate about the "unjust" relationship between age groups and its influence on public policy in Brazil calls for a critical review of the "facts" and for alternatives to counter-balance the narrow view of the "intergenerational equity" perspective. Within this spirit, we would like to discuss here some findings from the World Values Survey for Brazil and comment on Turra and Queiroz's recent work.

When jobs are scarce, should older people be forced to retire from work early?

The World Value Survey question we analyse is "When jobs are scarce, should older people be forced to retire from work early?", which was asked in 1991 and again in 1997. The likelihood of agreeing with forced retirement when jobs are scarce was $69 \%$ for the average respondent in 1997 compared to $31 \%$ in 1991. Although support for forced retirement greatly increased from 1991 to 1997 , the pattern of the responses did not vary according to individual characteristics over the six year period. Rather, the proportion agreeing that older people should be forced to retire from work early when jobs are scarce changed at a constant rate for individuals of varying 
characteristics as shown in Table 1 in the Appendix.

Our findings in a multivariate analysis of support for forced retirement when jobs are scarce show that education and income are negatively associated with attitudes regarding forced retirement, when controlling for other variables. This demonstrates that persons with lower education and lower income are more likely to support forced retirement of the elderly. When the 1991 and 1997 data are combined, the predicted probability of agreeing with forced retirement of the elderly in times of unemployment is $60 \%$ for people with lower levels of education. This probability decreased to $42 \%$ and $25 \%$ for individuals in the middle and upper levels of education, respectively. In terms of income, the predicted probability of agreeing with forced retirement was 51\% for individuals in the lowest income and decreased to $24 \%$ for individuals in the highest income group. In separate analyses for the two years, we show that support for early retirement was higher in 1997, holding other variables constant. In another words, the pattern of answers did not vary over the six year period, according to individual characteristics included in the model, such as age, sex, status marital and skin color.

The growth in negative public opinion about elderly people is also understandable in the context of the social security reforms and the persistent inequalities occurring in the 1990s along with the projections that the Brazilian population aged $60+$ will be increasing its representation. Also, the government's social spending and social security reform were framed as a competition between generations for scarce resources, both by economists and the media, popularizing the "intergenerational equity" approach in Brazil (BARROS et al., 1999; BARROS; CARVALHO, 2003; GIAMBIAGI, 2004, 2010; LAVINAS; GARSON, 2003; TURRA; QUEIROZ, 2009). The influence of mass media on public opinion regarding the situation of different age-sex groups and their benefits was an almost everyday headline (GOLDANI, 2005; NERI, 2003) and although we can't measure its impact on public opinion, findings from other countries suggest that the media help to increase negative perceptions about the elderly. Studies in the United States that examined how young, middle-aged, and older people respond to information from a media source about their age group's relative economic privilege or disadvantage, showed that framing intergenerational comparisons as favorable or unfavorable to one's own age group affects perceptions of age discrimination and age-based spending support. Thus it is reasonable to expect that age group status - that responds differently to the policy debate and to the perception of an intergenerational equity - is also part of the explanation of the higher percentage of Brazilians supporting the elderly early retirement due to scarcity of jobs in 1997.

Some secondary statistics also reinforce our argument that contextual factors are important influences on individual behavior. For example, there were two reforms of the Brazilian social security system, in 1993 and 1999, covering the areas of social insurance, social assistance and health, which contributed to an expansion of social security coverage. The proportion of retired people aged 60 years and over increased from $59 \%$ to $92 \%$ in rural areas and from $49 \%$ to $68 \%$ in urban areas during the 1981 to 2001 period (WAJNMAN et al., 2005). Retirement benefits became an important source of income for families and helped to combat poverty. However, activity rates of the elderly did not decline. Rather, male activity rates of the elderly increased slightly from $36 \%$ to $38 \%$ in urban areas and remained at $60 \%$ in rural areas, while female activity rates increased from $9 \%$ to $12 \%$ in urban areas and from $13 \%$ to $19 \%$ in rural areas (WAJNMAN, 2005, p. 463). Therefore, the increase in benefits and in the participation of the elderly in the labor force as well as the greater public awareness of the dispute for resources between age groups becomes a plausible explanation for the doubling of Brazilians supporting the idea that older people should be forced to retire from work early when jobs are scarce. Finally, during the 1990s, government efforts at reducing social inequalities among older persons resulted in 
the National Council of the Rights of Older Persons, which organized conferences, public hearings, and workshops to foster participation. These efforts culminated in the creation of the "Statute for the Elderly". The original project (Law, $n$ - 3.561) is from 1997 but received final approval in 2006.

\section{Age discrimination and demographic changes in Brazil}

Through an apparently neutral demographic perspective of the so-called "demographic dividends" or "window of opportunity" - which emphasize the advantages of changes in age structure for economic development - Turra and Queiroz (2009) call attention to the absence of appropriate policies to take advantage of the temporary benefits of population changes and of "generational inequities" in Brazil. They claim that the elderly receive the greatest benefits of social security reform because of poorly-designed policies that do not consider the temporary opportunities afforded by the demographic transition. In their words, Brazil is losing its "window of opportunity". To illustrate that we quote from this study and in fairness to the authors, we seek to put their words in context and then we quote widely to diminish the risk of misinterpretation.

In this article we sustain that some developing countries have missed the opportunities that the changes in population dynamics can offer to the economy, by maintaining policies that are less efficient than is desirable. In this sense, Brazil is noteworthy due to the historical low levels of education and of increasingly large public pension systems. In 2004, Brazil's public pension systems transferred roughly $12 \%$ of the GDP from the economically active population to the elderly, a significant amount for a country in which only $6 \%$ of the population is over 65 years old.

(...) The conclusions reveal that policymakers in Brazil have neither made good technically based decisions, nor have they taken into account the temporary nature of demographic transitions. Although we agree that no society should simply "sit down and watch" how their citizens grow poorer in old age without providing any public assistance (including income transfers), policymakers have reduced the beneficial effects of the demographic transition and have worsened financial problems derived from the aging population by providing new benefits without demanding contributions (for example, as what happened in the case of the inclusion of rural workers in 1988) and by not approving reforms to stimulate payment of contributions. This lack of vision has also reduced tax payments, derived from the growth in the available labor force.

Other conclusions of the present analysis should be seen as alert signs. First, the short-term effects of the age structure on the rate of population aging, as a consequence of much higher fertility rates in the past, have given social security more time, about 30 or 40 years, for the dependency rate to reach low enough levels to avoid a financial crisis. Second, policy simulations indicate that in view of the higher minimum age for retirement and elimination of tax evasion, among other factors, the rates of social security dependence could increase, and could help fulfill obligations, maintain the elderly population above the line of poverty and create the necessary future conditions for economic growth. (TURRA; QUEIROZ, 2009 , p. 162-163, our translation).

Following our central assumption in this paper - that the way we frame ageism and intergenerational relations will have a significant effect on both perceived age discrimination and support for age-based social programs - we would like to offer a different perspective on Turra and Queiroz's analysis. In doing this, we underscore the limits of the "generational equity approach" and of the "window of opportunity", which we believe overemphasize the role of demographic changes and seem too deterministic. In this case we are supported by secondary information and guided by our view of the relationship between population and development in broad terms and not only restricted to population and economic growth. We assume that the questions we ask and the point of view we take often reflect our values, whether those are an enthusiasm for feminist or civil-rights inspired activism or a belief in the importance of equal opportunities of conditions for all members of the society. In fact, even the categories and labels we use often reflect value-based assumptions; however it does not mean that all data are suspect or that all interpretations of data are equally valid. What is important is to keep in mind the need for treating so- 
called facts critically and for questioning their origins and purposes.

We argue that the association between changes in the age structure and social security finances, which is at the center of the demographic dividends argument, deserves more discussion and analysis, especially given the importance of this argument for large-scale public policies. Such analyses need to incorporate a series of elements that examine the relationship between age groups beyond the level of public expenditure alone. Among those elements, we discuss three: 1 . The need to locate the safety net provisions for different agegroups in the broad context of income and social inequalities; 2 . The need to consider the principles on which public support is provided; and 3. The need for appropriate information on social care and other service use and the outcomes and needs for different age groups as a necessary condition to fully discuss "social justice" among age groups.

First, forgetting to put age discrimination within the broader system of inequalities not only limits the understanding of the complexity of the process of policy decision making but it can also lead to misleading conclusions of the impact of the policies. Thus, the so-called current "privileges" of the Brazilian elderly must be viewed at the macro and micro levels, to the extent that benefits for the elderly not only improve their personal well-being but also provide resources for their extended family. More than three quarters of the population, 60 years or older, was receiving some type of pension benefits $(77 \%)$ in 2002 , which accounted for a substantial part of their household income. When the elderly lived with other family members, their incomes represented almost $60 \%$ of the total family income in urban families and $70 \%$ of those living in rural areas (WAJNAMAN, 2005). In fact, there are clear cases of reverse intergenerational flows with the elderly providing for the young
(CAMARANO, 2005), but there is also a substantial amount of elderly people in need of care..$^{5}$ Therefore, acknowledging agegroup inequality as part of a multiple system of discrimination, or in terms of the other "isms" in Brazil, requires keeping in mind the complexity of intersections of age, gender, race and class. This is just an example of the several recent portrayals of Brazilians under multiple inequalities (PINHEIRO et al., 2008). Thus, an integrated system of policies that gets at the complex and historical system of inequality in the country seems to be a more appropriate and better way to view social security benefits and their share among age groups.

A second issue has to do with recognizing the Constitutional principles on which public support is provided. Public policies are oriented both by a technical logic and the ability of groups to bring pressure on the state. The Brazilian social security system is clearly a result of pressure from various interest groups during the development of the 1988 National Constitution, which guided the reforms to the system and improved on citizen rights. The government is mandated to enforce the constitutional principles through laws and policies and, with the participation of civil society, it has created a set of public policies that are both redistributive and recognize diverse interests. A polemic example of the nature of Brazil's safety net for older persons is the fact that it is based primarily on non-contributive social programs. For example, the Continued Assistance Benefit (LOAS) provides a monthly minimum salary to persons over 65 and those with disabilities, whose families in both cases have a per capita below a quarter of the minimum salary. ${ }^{6}$ Therefore, as new groups of beneficiaries emerge and social spending increases, the relationship and power structure among social and age groups seems to have changed and threatens traditional privileges. Thus,

\footnotetext{
${ }^{5}$ In 2009 there were 2.1 million elderly Brazilians under family care, and another 100 thousand that were institutionalized. The majority of them were had female caretakers (CAMARANO, 2009).

6 It is important to note that the majority of Brazilian households receiving social benefits are headed by a black person, such as the LOAS (Benefício de Prestação Continuada-Continued Assistance Benefit) (60\%) and the Child Work Eradication Program (68\%).
} 
not only technical issues such as those regarding "demographic dividends" but the Constitutional guarantees of negotiation among segments of society and the state must be considered in the creation of social policies in Brazil.

Third, the longitudinal data needed to provide information on social care and other service use, or the outcomes and needs for different age groups, are not available for Brazil. The Report of Social Spending of the Central Government has been the main source of data for addressing generational bias in social spending, because it describes the government's revenue sources with detailed information. However, it is crosssectional and thus based on a static methodology of today's reality, neglecting the dynamic nature of life chances. It is important to remember that the "the core welfare issue is not how many people at any given time are low-paid or ill-housed but how many are likely to remain persistently low-paid or ill-housed" (ESPING-ANDERSEN et al., 2002, p.6).

Turra and Queiroz's counterfactual projections of social support ratios showing how demographic and economic changes can have an impact on social security and even diminish the potential demographic dividend, assume too much causality. Their implicit causal arguments are critical and based on correlations in cross-sectional data. They assume that conditions of previous age structures in which there were many children, will be reproduced in the current one. We can't generalize with any degree of certainty from previous facts and assume that a small number of children today are also likely to generate better education, jobs, health, and happiness, with a high degree of certainty. Statistically, we know that when two social trends vary together, it is not possible to conclude that one causes the other. That is, the changes in age structure do not support a casual interpretation about the impact on better quality of life of Brazilians. Seen in a different way, a growing elderly dependency ratio does not predict the failure of the social security system, as suggested, until we know what will happen with other variables, especially those outside of the population structure. What we want to convey here is that causality is extremely difficult to nail down and we must read research accounts suggesting causality with a critical eye. The complexity hidden within "simple" correlation cannot be understood or communicated with simple sound bites like "losing the window of opportunity" or the "clash of generations". ${ }^{7}$

Even the fairest social scientist will have to make choices about what questions to ask, what counts as a good result, and on what basis or theoretical approach one draws conclusions on. The point here is not that the authors' claims are wrong, but we are suggesting that they do not provide enough evidence for the causal assertions and policy conclusions they are making. In suggesting an alternative way to see the question, we propose that it is always legitimate and possible to make policy arguments on moral or value grounds. Thus, the accuracy of facts appears as a first step, but a second important step is to examine critically the way people interpret the relationship of one fact to another. Therefore, when we question the intergenerational equity and windows of opportunity approaches, we question the purpose for making these facts known and we seek to make transparent what we know about the relationship of these facts to other facts or trends not mentioned in the analysis.

\footnotetext{
${ }^{7}$ Certainly, a higher proportion of children and youth demand more investments and tend to use more resources than they contribute to the economy, compared to young adults and adults in productive age. However, it is possible that some of the negative effects (of too many children and youth) on the economy of the country come from the fact that their household/ family conditions (lower income and its consequence in terms of reduced resources) were responsible, at least in part, for children's difficulties and the need of larger economic investments from the government in the past. However, we would argue that, even with fewer children, if the conditions of those families don't change, the need for government spending continues and can be more acute in the light of the growing presence of the elderly in those families. Therefore, to attribute the responsibility of worsening social security finances to the change in demographic rates or dependency ratios and some specific policies means to assume that all other conditions will be maintained, including the same stratified and unequal opportunities of achievement and social economic structure.
} 
In conclusion, a "fact" like the change in the population age structure can and should become part of the dialogue about social and political issues. The problem is how this fact becomes a symbol of an issue in dispute like changes in the social security benefits system or redistribution of resource among age groups. Certainly, most social scientists care about the social and political issues they discuss - Turra and Queiroz are clear about their concerns about the situation of the elderly in Brazil. What is difficult is to strike a balance between these concerns and the facts they are analyzing and reporting on.

Finally, we would like to suggest that the evaluation of the social effects of social programs on the well-being of the population at different ages could be a good counterpoint for the evaluation of the studies concerned with the "finances of the social security system and the privileges of the older"8 or even in terms of the "missed window of opportunities". In fact, some recent results of the expansion in coverage, quality and efficacy of the social security system suggest a series of benefits for different age groups. The infant mortality rate in Brazil fell by $65 \%$ in the decade between 1996 and 2006 but it is still the third-worst in South America $(20.4$ per 1,000$)$. Some of the high-priority social programs like the efforts to eradicate hunger ("Fome Zero"), creating youth employment ("Primeiro Emprego"), and unifying conditional cash transfer/programs for greater effectiveness in reducing poverty ("Bolsa Família"), and the recovery of the purchasing power of the minimum wage in the past eight years contributed to making the poorest Brazilians less vulnerable than they were before. However, high levels of income and social inequality persist. Therefore, in searching for a more complete picture and understanding of policy effects among different age groups, we need a diversity of policy approaches with concerns that go beyond the level of public expenditure alone, like Amartya Sen's capability approach. Largely used as an ideal for the analysis of age discrimination in publicly supported social care for adults, Sen's focus is to ensure that people have the same substantive freedoms, meaning the capability to achieve the same outcomes, should they choose to do so. Thus, the measure of inequality would be in terms of the measured differences in capabilities between age groups (SEN, 1999; 2006).

\section{Final comments}

With the aging demographic trend, it is especially timely for Brazilian researchers and policymakers to understand how society can shed its institutionalized ageism and promote a society for all ages. Although we cannot be entirely sure about why and how it happens, the Brazilian findings illustrate that the practice of ageism and age discrimination is common and not only diminishes the value of the old but also puts their lives at risk, as suggested in the case of AIDS treatment. The term "ageism" is still not widely known or understood amongst Brazilians and it is hardly a focus of policies. However, it is fair to say that although the positive and negatives aspects of ageism are not explicit, the issue of age has appeared on the agenda of governmental policies in the past decade and is part of the current debate on demographic changes and the need for social security reform. Thus, legal statutes intended for various age groups like the Statute for the Old, The Statute for Children and Adolescents, and Youth Employment Job Training, along with the social programs enforcing these statutes, are good examples of the acknowledgement of the needs of different age groups. They reinforce the idea of a very age-specific public policy system in Brazil.

National and international studies found that older adults might be at a higher risk of perceived age discrimination damage to their wellbeing. These studies suggest that

\footnotetext{
8 At the heart of this debate is whether funding for social programs that benefit particular age groups should be eliminated. Calls for "generational equity," for example, may be seen as political strategies to legitimize reductions in government spending.
} 
increased awareness of ageist practices and cognitions may help to reduce the internalization of ageist beliefs and that it is important for social programs to be created to foster public awareness of the consequences of age discrimination. While age discrimination is a phenomenon that many people will face as they grow older, it can be fought using interventions and social programs as well as through the dissemination of information about aging. To combat ageism an important question is "What are the old for?" If older Brazilians are viewed just as an expense item on entitlement budgets, then we can understand the alarm of policymakers and some economists about the costs of social security and the future of the elderly. On the other hand, if the answer to "What are old people for?" entails contribution by the old to all generations and the fact that "the old are yesterday's young", who have received more resources at an earlier stage in their lives, then we can better understand the complexity of the positive/ negative balance with regard to the debates on intergenerational equity and age-based social policy in Brazil.

Thus, alternative perspectives for understanding ageing and its impacts are very important to guide policies and chiefly to the wellbeing of the individuals. We argue that in fact population needs should be viewed with attendant changes in expectations, attitudes and policies within the Brazilian context of multiple discriminations. We agree that the alarmism that an ageing society increases the dependency ratio, should be countered by some lesser-publicized facts such as the increased participation of women in the labor force, the vast quantities of reciprocal intergenerational help and income that the elderly often provide to families and the return of grown children to live with their parents. It is also important to note here that this is not merely an exchange for help, but there is proof of a strong intergenerational emotional bond. This has been described as a new form of extended family, based on 'intimacy at a distance'. Therefore, new trends and approaches call for a notion of age 'dependency' in a broad and very different light. But after all, an open question is: can a 'just' sharing-out of resources ever be achieved between different generations and cohorts? As Macnicols (2006, p. 49) suggests "the problem is that a longitudinal, lifespan perspective uncovers a subtle mixture of negative and positive age discriminations experienced by individuals as they move through the life course and a further complexity is introduced by the intersecting variables of class, race and gender.

Finally, to acknowledge ageism as a problem is the first step to eliminate it. The next step it is to choose methods to make individuals aware of its consequences. Paulo Freire's intervention method appears to be helpful for recognizing age discrimination and there are also institutions capable of carrying out intervention programs. There is, for example, a strong network of autonomous and self-organized groups and civic organizations, including 338,000 registered private foundations and non-profit associations, which collectively employ 1.7 million persons across the country (Brazilian Report). Despite divergences among competing umbrella organizations, trade unions are still strong political actors. Despite the fact that mobilization capabilities diminished during the 1990s and the level of trade union organization is on decline, trade unions are still important to many sectors of workers and can play an important role in fighting ageism in the labor market (Brazilian Report). Therefore, implementation of the legislation outlawing unfair discrimination by age is important not only in employment and training but in general, and should be brought forward as a Government plan in the model of the EU's recent experience.

9 See Thomas (2004), for a broad discussion of this question. 


\section{References}

ADELMAN, M. Stigma, gay lifestyles, and adjustment to aging: A study of later-life gay men and lesbians. Journal of Homosexuality, 20, p. 7-32, 1991.

AGE CONCERN ENGLAND. The Agenda 2008. London, Age Concern England, 2008.

BARROS, R. P.; CARVALHO, M. Desafios para a política social brasileira. Rio de Janeiro: Ipea, 2003 (Texto para discussão, 985).

BARROS, R.P. de; MENDONCA, R.; SANTOS, D. Incidência e natureza da pobreza entre idoso no Brasil. In: CAMARANO, A. A. (Org.). Muito além dos 60: os novos idosos brasileiros. Rio de Janeiro, IEA, 1999, p.221-250.

BERGER, R. (Ed.). Gay and gray: the older homosexual man. New York: Harrington Park, 1996.

BERNARD, M. A.; MCAULEY, W. J.; NEAL, K. S.; BELZER, J.A. The impact of exposure of medical students to healthy elders. Poster 410. Presented at the American Geriatrics Society Annual Meeting. Chicago, May 9-13, 2001.

BRENNAN, C.; CARMICHAEL, F.; INGHAM, B.; PRASHAR, A.; DOBSON, J.; SHARIFI, S.; PORCELLATO, L. Ageism and employment: a survey of the literature in the context of current research agendas. Researching Ageism and Employment. Salford Business School, 2007 (Discussion paper/March).

BUTLER, R. Ageism: a foreword. Journal of Social Issues, n. 365, p. 8-11, 1980.

BYTHEWAY, B. Ageism and age categorization. Journal of Social, v. 61, n. 2, p. 361-374, 2005.

CAMARANO, A. A. (Org.). The new sixties in Brazil: the elderly brazilians and their new social roles. Rio de Janeiro: Ipea, 2005.

CHRIS, P. Globalisation and the future of ageing: developing a critical gerontology. Sociological Research Online, v. 8, n. 4, 2003.

COHEN, E. The complex nature of ageism: What is it? Who does it? Who perceives it? Gerontologist, v. 41, n. 5, p. 576-577, 2001.
COHEN, G. D. The mature mind: the positive power of the Aging Brain by Gene D. Cohen. Basic Books. New York, 2005.

COLLINS, P. H. Black feminist thought: knowledge, consciousness, and the politics of empowerment. New York: Routledge, 2000.

CORRAL, M. To What extent should government ensure citizen well-being? Americas Barometer Insights, Vanderbilt University, n. 16, 2009.

COUTO, M. C. P.; KOLLER, S. H.; NOVO, R.; SOARES, P. S. Avaliação de discriminação contra idosos em contexto brasileiro ageismo. Teoria e Pesquisa, Brasília, v. 25, n. 4, out./dez. 2009. Disponível em: <http:// www.scielo.br>.

CRENSHAW, K. Mapping the margins: intersectional, identity politics and violence against women of color. In: KIMBERLE, C. et al. (Eds.). Critical race theory: the writings that formed the movement. New York Press, 1995.

CRUZ, J. M. Police abuse in Latin America. Americas Barometer Insights, Vanderbilt University, n. 11, 2009.

CUDDY, A. J. C.; NORTON, M. I.; FISKE, S. T. This old stereotype: the pervasiveness and persistence of the elderly stereotype. Journal of Social Issues, n. 61, p. 267285, 2005.

DAVIDSON, K. Why can't a man be more like a woman? Marital status and social networking of older men. The Journal of Men's Studies, n. 22, September, 2004.

DONLON, M. M.; ASHMAN, O.; LEVY, B. R. Re-vision of older television characters: a stereotype-awareness intervention. Journal of Social Issues, n. 61, p. 307-319, 2005.

DUNCAN, C.; LORETTO, W. Never the right age? Gender and age based discrimination in employment. Gender, Work and Organization, v. 11, n. 1, p. 95-115, 2004.

EDGAR, D. Ageing: everybody's future. Family Matters, n. 30, p. 15-19, December 1991. 
ESPING-ANDERSEN, S. S. The generational conflict reconsidered. Journal of European Social Policy, v. 12, n. 1, p. 5-21, 2002.

FERREIRA-ALVES, J.; NOVO, R. F. Avaliação da discriminação social de pessoas idosas em Portugal. International Journal of Clinical and Health Psychology, n. 6, p. 65-77, 2006.

FOUCAULT, M. The birth of the clinic: an archeology of medical perception. Kindle Edition, 1973.

Discipline and punish: the birth of the prison. Harmondsworth: Penguin, 1977.

FREIRE, P. Pedagogy of the oppressed. New York: Continuum, 1993.

FREITAS, E. V.; L.PY, A. L.; NERI, F. A.; CANÇADO, M. L. G.; ROCHA, S. M. da. (Orgs.). Tratado de geriatria e gerontologia. Rio de Janeiro: Editora Guanabara Koogan, 2002.

GARSTKA, T. A.; SCHIMITHT, N.; BRANSCOMBE, N. R.; HUMMERT, M. L. How young and older adults differ in their responses to perceived age discrimination. Psychology of Aging, n. 19, p. 326-335, 2004.

GARSTKA, T. A.; HUMMERT, M. L.; BRANSCOMBE, N. R. Intergenerational inequity. Journal of Social Issues, v. 61, n. 2, p. 321-342, 2005.

GIAMBIAGI, F. Diagnostico da Previdência Social no Brasil. O que foi feito e o que falta reformar. In: Seminário DIMAC, 164. Rio de Janeiro: Ipea, 2004.

GILLEARD, C.; HIGGS, P. Cultures of ageing: self, citizen and the body. Prentice Hall, Harlow, 2000.

GILES, H.; SCOTT, R. A. Ageism across the lifespan: towards a self-categorization model of ageing. Journal of Social Issues, v. 61, n. 2, p. 389-404, 2005.

GOLDANI, A. M. Intergenerational contracts and the reconstruction of the Welfare State. Why should we re-think this relationship in Brazil? In: CAMARANO, A.A. (Org.). The new sixties in Brazil: the elderly brazilians and their new social roles. Rio de Janeiro: Ipea, 2005, p. 211-252.
Mulheres e envelhecimento: desafios para os novos contratos intergeracionais e de gêneros. In: CAMARANO, A. A. (Org.). Muito além dos 60: os novos idosos brasileiros. Rio de Janeiro: Ipea, 1999, p.75-114.

GOLDIN, A. Labor and fundamental human rights: is discrimination law doing the job it supposed to do? The Latin American Countries. Conference on Labour Law and Labour Market in the New World Economy. Milan, 2010.

GERENCHER, K, A pervasive fatalism. Many ill seniors succumb to medical 'ageism'. Vital Signs, June 19, 2003.

IBGE - Instituto Brasileiro de Geografia e Estatística. Complete mortality tables 2008. In 2008, life expectancy of Brazilians reached 72.86 years of age. Social Communication. Rio de Janeiro, December 2009. Disponível em: <www.ibge.gov.br>.

$\mathrm{KALISH}, \mathrm{R}$. A. The new ageism and the failure models: a polemic. Gerontologist, n. 19, p. 398-402, 1979.

KIMMEL, M. Manhood in America. New York: Free Press, 1997

LAVINAS, L.; GARSON, S. Gasto social no Brasil: transparência, sem participação econômica. Rio de Janeiro: Universidade Federal Fluminense, 2003.

LAYDER, D. Understanding social theory. Sage Publications Ltd., 1994

LEIBING, A. The old lady from Ipanema: changing notions of old age in Brazil. Instituto de Psiquiatria, Universidade Federal do Rio de Janeiro, 2004.

LEONARDELLI, G. J.; ZACARY, L. T. The negative impact of perceiving discrimination on collective well-being: the mediating role of perceived in group status. European Journal of Social Psychology, n. 33, p. 507-514, 2003.

BARBARA, J. L. Modernization and the status of the frail elderly: perspectives on continuity and change. Journal of CrossCultural Gerontology, v. 5, n. 4, p. 345-374, 1990. 
LORETTO, W.; DUNCAN, C.; WHITE, P. Ageism and employment: controversies, ambiguities and younger people's perceptions. Ageing and Society, v. 20, p.279-302, 2002.

MACNICOL, J. Age discrimination: an historical and contemporary analysis. Cambridge University Press, 2006.

MANNHEIM, $K$. The problem of generations. In: MANHEIM, K. Essays on the sociology of knowledge. Collected Works, volume Five. Paul Keckskemeti (Edit). London, 1957.

MINICHIELLO, V.; BROWNE, J.; KENDIG, H. Perceptions and consequences of ageism: views of older people. Ageing and Society, n, 20, p. 253-278, 2000.

MUNNELL, A.; SAAS, S. A. Working longer: the solution to the retirement income challenge. The Brookings Institution, 2008.

NELSON, T. Ageism: prejudice against our feared future self. Journal of Social Issues, n. 61, p. 207-221, 2005.

NERI, A. L. Qualidade de vida no adulto maduro: interpretações teóricas e evidências de pesquisa. In: NERI, A. L. Qualidade de vida e idade madura. Campinas: Papirus, 1993.

. Atitudes e crenças sobre velhice: análise de conteúdo de textos do jornal O Estado de S. Paulo publicados entre 1995 e 2002. In: VON SIMSON; NÉRI; CACHIONI (Orgs.). As múltiplas faces da velhice no Brasil. Campinas: Átomo e Alínea, 2003.

Palavras-chave em gerontologia. Campinas: Alínea, 2005.

Atitudes em relação a velhice: questões científicas e políticas. In: FREITAS. Tratado de geriatria e gerontologia. Rio de Janeiro: Guanabara Koogan, 2006.

NEUGARTEN, B. L. The end of gerontology? In: NEUGARTEN, D. A. (Ed.). The meanings of age: selected papers of Bernice L. Neugarten. Chicago, IL, 1996.

NUSSBAUM, J. F.; PITTS, M. J.; HUBER, F. N.; KRIEGER, J. R. L.; OHS, J. E. Ageism and ageist language across the life span: intimate relationships and non-intimate interactions. Journal of Social Issues, n. 61, p. $287-305,2005$.
PALMORE, E. B. The ageism survey: first findings. The Gerontologist, n. 41, p. 572-575, 2001.

PALMORE, E. B. Research note: ageism in Canada and the United States. Journal of Cross-Cultural Gerontology, n. 19, p. 41-46, 2004.

PINQUART, M. Good news about the effects of bad old-age stereotypes. Experimental Aging Research, n. 28, p. 317-336, 2002.

PINHEIRO, L. et al. Retrato das desigualdades de gênero e raça. Brasília, DF: Ipea, SPM, Unifem, 2008.

POWELL, J. Theorizing gerontology: the case of old age, professional power, and social policy. United Kingdom Journal of Aging and Identity, v. 6, n. 3, 2001.

QUADAGNO, J.; ASCHENBAUM, A.; BENGSTON, V. L. Editing the agenda of research on cohorts and generations: theoretical, political, and policy implications. In: BENGSTON, V. I.; ASCHENBAUM, A. (Eds.). The changing contract across generations. New York: Aldine De Gruyter, 1993.

ROTHERMUND, K.; BRANDSTÄDTER, J. Age stereotypes and self-views in later life: evaluating rival assumptions. International Journal of Behavioral Development, n. 27, p. 549-554, 2003.

SAMPAIO, R. F.; NAVARRO, A. G.; MARTÍN, M. M. Work-related disabilities and worker's disabilities in rejoining the labor market. Cad. Saúde Pública, v. 15, n. 4, p. 809-15, Oct.-Dec. 1999.

SARGEANT, M. The law on age discrimination in the EU. Kluwer Law International, BV, The Netherlands, 2008.

SEN, A. Social justice and the distribution of income. In: ATKINSON, A. B.; BOURGUIGNON, F. (Eds.). Handbook of income distribution, v. 1 , chapter 1, 2000, p. 59-85.

Reason, freedom and well-being. Utilitas, Cambridge University Press, v. 18, n. 1, 2006.

Capability and well-being. In: NUSSBAUM, J.F.; SEN, A. The quality of life. Oxford: Clarenden Press, 1999. 
SCHMIDT, C. As relações entre avós e netos: possibilidades co-educativas. Dissertação (Mestrado em Educação). Porto Alegre, Escola de Educação, UFRGS, 2007.

SOUZA, E. M. Integração entre gerações na promoção da saúde: estudo qualitativo no Brasil. Rev. Saúde Pública, v. 37, n. 4, p. 463-9, 2003.

THOMPSON Jr., E. H. Older men's social participation: the importance of masculinity ideology. The Journal of Men's Studies, n. 22, September, 2004.

THOMAS, W. H. What are old people for? How elders will save the world. Vanderwyk \& Burnham, Acton, MA., 2004.

TOWSEND-BELL, E Intersectional praxis. Paper presented at the American Political Science Association Annual Meeting. Toronto, Canada, 2009.

TURRA, C. M.; QUEIROZ, B. L. Antes de que seja demasiado tarde: transición demográfica, mano de obra disponible y problemas de la seguridad social en el Brasil. Notas de población, Cepal, n. 86, 2009.

VALENTE, M. AIDS-Latin America: neglect, 'ageism' put older people at risk. Inter Press Service, n. 29, December 2008.
VELOZ, M. C. T.; NASCIMENTO-SCHULZE, C. M.; CAMARGO, B. V. Representações sociais do envelhecimento. Psicologia, Reflexão e Crítica, n. 12, p. 479-501, 1999.

WAJNMAN, S.; CARVAHAES, L.; COSTILLA, $\mathrm{H}$.; MONTE, S. The capital for the old age. The new sixties in Brazil: the elederly brazilians and their new social roles. PEA, 2005, p. 439-464.

WILLIAMSON, J. B.; WATTS-ROY, D. M.; KINGSTON, E. R. The generational equity debate. Columbia University Press, 1999.

WOOLF, L. M. Gay and lesbian aging. Webster University, 1998. Disponível em: < http://www. webster.edu/ woolflm/oldergay $>$.

WRIGHT, E. O. Class counts: comparative studies in class analysis. Cambridge University Press, 2000.

YUNES, M. A. M.; SZYMANSKI, H. Resiliência: noção, conceitos afins e considerações críticas. In: TAVARES, J. (Ed.). Resiliência e educação. São Paulo: Cortez, 2001, p. 13-42.

\section{ANNEX}

TABLE 1

Results of probit analysis of attitudes regarding forced retirement Brazil - 1991-1997

\begin{tabular}{lc}
\hline Variable & Coefficient (s.e.) \\
\hline Intercept & $0.78(0.18)^{\star * *}$ \\
Age & $-0.01(0.02)$ \\
Male & $-0.07(0.05)$ \\
Skin color & \\
$\quad$ White & $-0.14(0.11)$ \\
$\quad$ Black & $-0.08(0.12)$ \\
Married & $-0.00(0.05)$ \\
Education & $-0.47(0.06)^{\star * *}$ \\
Income & $-0.08(0.02)^{\star \star *}$ \\
Year 1997 & $0.98(0.21)^{\star * *}$ \\
Interaction terms & \\
$\quad$ Year x age & \\
Year x education & $0.01(0.03)$ \\
Year x income & $-0.05(0.04)$ \\
Pseudo R & $-0.00(0.09)$ \\
\hline
\end{tabular}

Source: World Values Survey, $n=2,737$.

${ }^{*} p<.05 ;{ }^{* *} p<.01 ;{ }^{* * *} p<.001$ 


\section{Resumo}

\section{"Ageismo" no Brasil: O que significa ? Quem pratica? O que fazer com isto?}

O principal objetivo deste artigo é chamar atenção para o ageismo e a idade como parte do sistema de preconceito e discriminação no Brasil. Embora o ageismo e a discriminação por idade sejam termos frequentemente usados como sinônimos, o ageismo refere-se essencialmente às atitudes que os indivíduos e a sociedade têm frequentemente com os demais em função da idade, enquanto a discriminação por idade descreve a situação em que a idade é o fator decisivo. Um exemplo de discriminação por idade é o empregador que decide contratar, promover, retreinar ou aposentar/dispensar um funcionário com base somente na idade. Ainda que reparar na idade de um indivíduo não seja inerentemente ofensivo, agir por estereótipos baseados em idade é claramente um preconceito contra o indivíduo, que frequentemente não é contestado pela sociedade. O presente artigo se baseia em achados empíricos e no conhecimento acumulado sobre a discriminação do idoso, e discute as posições teóricas que ligam a discriminação etária ao ageismo. Defendemos que o ageismo e a prática de discriminação por idade no Brasil devem ser vistos como parte das múltiplas formas de discriminação sofridas pelos indivíduos. A premissa central que orienta este trabalho é de que a forma como enquadramos o ageismo e as relações intergeracionais tem um efeito significativo tanto na discriminação baseada na percepção da idade quanto no apoio a programas sociais específicos por idade. llustraremos descrevendo o caso do Brasil.

Palavras-chave: "Ageismo”. Política. Iniquidade. Mudanças demográficas.

\section{Resumen}

\section{"Edadismo" en Brasil: ¿qué significa? ¿Quién lo ejerce? ¿Qué se puede hacer?}

El objetivo principal de este artículo es llamar la atención sobre el edadismo y la edad como parte de un sistema de prejuicio y discriminación en Brasil. A pesar de que el edadismo y la discriminación por edad sean términos frecuentemente usados como sinónimos, el edadismo se refiere esencialmente a las actitudes que los individuos y la sociedad tiene frecuentemente con los demás en función de la edad, mientras que la discriminación por edad describe un contexto en el que la edad es el factor decisivo. Un ejemplo de discriminación por edad es un empleador que decide contratar, promocionar, reciclar o jubilar/prescindir de un funcionario en base solo a la edad. Pese a que fijarse en la edad de un individuo no sea inherentemente ofensivo, actuar por estereotipos basados en la edad es claramente un prejuicio contra el individuo, que muy a menudo no es rebatido por la sociedad. El presente artículo se basa en hallazgos empíricos y en el conocimiento acumulado sobre la discriminación al anciano, además de discutir las posiciones teóricas que relacionan la discriminación por franja de edad al edadismo. Defendemos que el edadismo, como práctica de discriminación por edad en Brasil, debe ser visto como parte de las múltiples formas de discriminación sufridas por los individuos. La premisa central que orienta este trabajo es que la forma en la que encuadremos el edadismo y las relaciones intergeneracionales tiene un efecto significativo, tanto en la discriminación basada en la percepción de la edad, como en el apoyo a programas sociales específicos por edad. Ilustraremos mientras describimos el caso de Brasil.

Palabras-clave: "Edadismo”. Política. Iniquidad. Cambios demográficos. 